\title{
Marine natural products: new results from Mediterranean invertebrates
}

\author{
G. Cimino, S. De Rosa, S. De Stefano and G. Sodano \\ Istituto per la Chimica di Molecole di Interesse Biologico \\ del C.N.R. - Via Toiano n. 6, 80072, Arco Felice, Naples, \\ Italy.
}

\begin{abstract}
This paper covers the chemical work, recently effected in the authors' laboratory, on three topics: 1) the defensive behaviour of Mediterranean opistobranchs; 2) marine zoochromes; 3) a new class of alkaloids from a marine sponge. Biosynthetic experiments, performed on the dorid nudibranchs Dendrodoris limbata and Dendrodoris grandiflora, were aimed at the understanding of the origin and the fate of the harmful molecules used by the molluscs to deter potential predators. New organic compounds were characterized from the opisthobranchs Janolus cristatus and Aglaja depicta. The recent determination of the structure of uranidine (27), the yellow zoochrome of the sponge Verongia aerophoba, stimulated the chemical studies of calliactine, the zoochrome of the sea anemone Calliactis parasitica, and of a pigment co-occurring with hallachrome (29), the red zoochrome of the sea-worm Halla parthenopeia. Some nitrogenous metabolites, belonging to a new class of alkaloids, were isolated from the sponge Reniera sarai and partially characterized, mainly on the basis of a $500 \mathrm{MHz}$ NMR study.
\end{abstract}

\section{INTRODUCTION}

In the beginning, our research on marine natural products was devoted mainly to structural determination of new organic compounds. In recent years we reverted to rather specialized topics such as the investigation of the defensive chemistry of nudibranch molluscs. Nudibranchs (Opistobranchia) use for their own defence chemicals deriving either from their diet or produced de novo by the molluscs (ref. 1). Biosynthetic experiments were performed on Mediterranean Dendrodorididae nudibranchs with the aim of knowing how the animal takes possession of the chemical weapons, where it stores them and how it avoids suffering from their noxious effects.

The recent great development of the spectroscopic techniques, particularly NMR and mass, has considerably eased the work of the chemists on natural products and has also opened new perspectives for them. In our research, these new techniques have remarkably facilitated the structural characterization of new metabolites from Mediterranean opistobranchs. However, we are currently using these great potentialities by performing structural studies on molecules which until now have resisted all chemical investigation. Among these, many marine zoochromes were previously noticed (ref. 2), but so far only little structural work on them has been reported. This could be due to the fact that many pigments are present in organisms only in small amounts and, besides this, they are often highly unstable. Starting from old reports we have performed studies on the zoochromes of the sponge Verongia aerophoba and of the actinia Calliactis parasitica, and on compounds related to the zoochrome of the sea-worm Halla parthenopeia.

Several years ago we found in the sponge Reniera sarai an exceptionally high concentration of unusual nitrogenous metabolites, but every attempt to investigate their structures failed. Only now have the two-dimensional (2D) NMR methods allowed a new approach to the understanding of the structural features of these new alkaloids. 


\section{MEDITERRANEAN OPISTHOBRANCHS}

The molluscs belonging to the subclass Opisthobranchia are characterized by the evolutionary loss of the external shell (ref. 3). Despite the lack of this characteristic mechanical defence only a few predators of these animals are known (ref. 4). This is due to the development in the animals of a series of defensive strategies (ref. 5) which include the use of chemicals to deter predators. Among the opisthobranchs, the order Nudibranchia contains the largest number of species. However, because of the small size of almost all the nudibranchs, only recently extensive chemical studies on these animals have been performed. A great number of organic compounds found in nudibranchs were previously known as metabolites of other marine organisms or were closely related to known marine metabolites (ref. 1). Accordingly, they should have a dietary origin, which has been sometimes well supported by field observations. After the first report (ref. 6) of defensive allomone, 9-isocyanopupukeanane (1) from the dorid Phyllidia varicosa, bioassays for toxic or antifee.dant activities have shown that a great number of dorid nudibranchs are che-mically armed against predators (ref. 7-12).

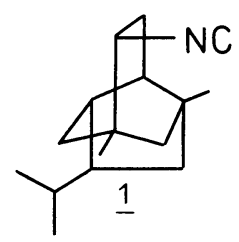

The majority of the noxious or toxic compounds are sesquiterpenoids. On the basis of the structure-activity relationships observed by all the research groups interested in this topic, it seems that the defensive activities of these terpenoids can be ascribed either to their carbon skeleton or to some particular functional groups. Our results on Mediterranean nudibranchs agree with this general feature. Bioassays on selected metabolites (ref. 7, 10) found toxic activity in sesquiterpenoids characterized by an isocyano group, as axisonitrile-1 (2), the metabolite found in Phyllidia pulitzeri, while terpenoids containing a furan ring, as longifolin (3), or displaying a drimane ske-

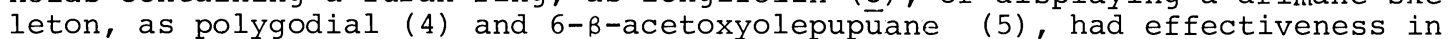
inhibiting feeding, even though the drimane compounds were remarkably more active.<smiles>C=C1CCCC2(C)CCC(C(C#N)C(C)C)C12</smiles>

$\underline{2}$<smiles>C/C(=C\Cc1occc1C)Cc1cc(C)co1</smiles>

3<smiles>CC1(C)CCC[C@]2(C)C1CC=C(C=O)[C@H]2C=O</smiles>

$\underline{4}$<smiles>CC(=O)O[C@@H]1OC=C2[C@@H]1[C@@]1(C)CCCC(C)(C)C([C@@H]1OC(C)=O)[C@H]2OC(C)=O</smiles>

5

Isocyanosesquiterpenes and furanosesquiterpenes could have a dietary origin, while the drimane sesquiterpenoids, absent in possible marine preys, could be synthesized de novo by the nudibranchs. Few examples of nudibranchs able to biosynthesize their own defensive chemicals are known (ref. 9, 12, 14). We provided the first evidence (ref. 14), reporting that Dendrodoris limbata is able to synthesize polygodial ( $\underline{4})$, the sesquiterpenoidic dialdehyde very active as antifeedant against marine and freshwater $\bar{L}$ ish. To introduce recent developments in this research it is necessary to summarize previous work. Biosynthetic experiments were performed in order to clarify 1) how the animal acquires its chemical defence, 2) where the animal stores its chemical defence, 3) how the animal avoids the noxious effects produced by its own chemical weapons.

Polygodial (4) is present in the dorsum of the animal, while in the digestive glands a mixture of biogenetically related to polygodial but biologically inactive sesquiterpene esters ( $\left.{ }^{6}\right)$, incorporating $\mathrm{C}_{18}-\mathrm{C}_{2} 0$ acid residues, was found (ref. 13). Biosynthetic experiments (ref. 14) have shown that both polygodial and the sesquiterpenoid part of the esters were de novo biosynthesized by the mollusc. The experiments were performed with $[2-\sqrt{4} \mathrm{C}]$ mevalonic acid which was injected into the digestive glands of the nudibranchs; after $24 \mathrm{~h}$ the animals were killed by freezing and the metabolites from the dorsum 
and from the digestive glands were separately analyzed. After the appropriate purifications to constant specific radioactivity, good incorporation was observed in polygodial (4) and in the drimane skeleton of the esters (6) which, after thermolysis, yielded radioactive euryfuran, (ㄱ) •

Dendrodoris grandiflora, as D. limbata, belongs to Dendrodorididae family and, as D. limbata, possesses among its metabolites polygodial (0.15 mg/animal), in the dorsum, and the mixture of esters 6 in the digestive glands. However in the dorsum the major component $(0.5 \mathrm{mg} / \mathrm{animal})$ is another sesquiterpenoid, 6- - acetoxyolepupuane ( $\underline{5})$, also active as antifeedant although to a lesser extent. It is closely related to olepupuane (8), a fish antifeedant drimane sesquiterpenoid which co-occurs (ref. 12) with polygodial in a series of porostome nudibranchs living in the Pacific Ocean.

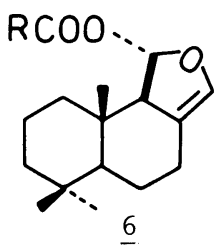<smiles>CC1(C)CCC[C@@]2(C)c3cocc3CCC12</smiles><smiles>CC(=O)OC1OC=C2C3CC(OC(C)=O)C(C)(C)CCC[C@@]3(C)C21</smiles>

In the digestive glands of D. grandiflora the esters 6 co-occur with a series of metabolites, for which a dietary origin seems likely. In fact, we have found some typical sponge metabolites, microcionins-1, -2, -3, -4 (9-12) and fasciculatin (13), which could derive from predation on the sponges Microciona toxystila (ref. 15) and Ircinia fasciculata (ref. 16), respectively. Along with these molecules the analysis revealed the presence of some new compounds, $14,15,16$, closely related to typical sponge metabolites and which could derive either from predation on unknown sponges or by modifications of known sponge metabolites.<smiles>CC1CCCC2(C)c3occc3CCC12C</smiles>

$\underline{9}$<smiles>CC1=CCC[C@H](C)[C@@]1(C)CCc1ccoc1</smiles>

$\underline{10}$<smiles>CC1CCCC(C)(C)/C1=C\Cc1ccoc1</smiles>

11<smiles>C=C1CCCC(C)C1(C)CCc1ccoc1</smiles>

12<smiles>CC/C=C/C=C/[C@H](C)CCC[C@H](C)/C=C/C(C)=C\CCCc1ccoc1</smiles>

$\underline{13}$<smiles>[CH][C@H](CCCCc1ccoc1)C[C@@](C)(O)C/C(C)=C/CCc1ccoc1</smiles>

15<smiles>CC[C@](C)(C/C=C(\C)[13CH2]C)CC1(C)CCc2cc(O)ccc2O1</smiles>

14<smiles>CC(=O)OC(/C=C(\C)C/C=C/C(C)=C/CCc1ccoc1)Cc1ccoc1</smiles>

16

Biosynthetic experiments (ref. 10) confirmed what we have just stated. As expected, the drimane sesquiterpenoids $(4,5,6)$ were found substantially labelled, while the radioactivity associated with the other terpenoids, after some purifications and simple chemical transformations, rapidly decreased to values slightly above the background. These results confirm the ability of the Mediterranean Dendrodorididae nudibranchs to synthesize de novo their own defensive weapons. This ability should be found in all the nudibranchs possessing drimane sesquiterpenoids and it, sometimes, may not be limited to these terpenes. In fact recently i.t was observed (ref.9) that the nudibranch Archidoris montereyensis is capable of direct biosynthesis of the 
terpenoic part of both sesquiterpenoic and diterpenoic acid glycerides, while Archidoris odhneri is able to biosynthesize a farnesic acid glyceride.

The finding of polygodial (4) raises questions about the damage which may be caused to the nudibranch itsele. It is well known that this fish antifeedant displays a series of biological activities (ref.17,18) which have been related to its ability to interact with primary amines in vivo (ref.19).

Toxicity tests have revealed that polygodial ( 4 ) is toxic to D. Iimbata. In fact when $\Delta(2 \mathrm{mg})$ was injected into the digestive glands of four specimens of $\mathrm{D}$. limbata, death of all the animals was observed within $16 \mathrm{hr}$. This experiment makes clear that, in D. limbata, polygodial should be biosynthesized in specialized cells, likely to the skin glands, and, being toxic to the nudibranch, it should be either eliminated through the skin or stored in the digestive glands as detoxified esters ( 6$)$. After this bioassay, an intriguing question has to be clarified regarding the metabolic relationship between polygodial and the drimane esters. In fact the esters could represent either the biogenetic precursors of polygodial, or the result of a detoxification process of 4. A third hypothesis is that two independent pathways lead to the biosynthesis in different sites of the structurally related sesquiterpenoids. We have performed on $D$. limbata two sets of biosynthetic experiments aimed at testing above hypotheses (ref. 20). In the two experiments, labelled mevalonic acid was injected into the digestive glands of 9 and 14 specirens,respectively. The animals were killed at various times between 3 and $77 \mathrm{hrs}$, and then the metabolites from the skin and from the digestive glands were extracted in the normal fashion. In both experiments significant levels of incorporation, increasing with time, were observed for both polygodial and esters. However, in the first experiment, the major specific incorporation was observed for polygodial, while in the second experiment it was associated with the terpenoic part of the esters. These results thus exclude a direct biogenetic relationship between polygodial and the mixture of esters. In Iact, in a biosynthetic experiment the specific radioactivity of a precursor should be higher than that found in the metabolic products or at least, following the experiment at different times, the radioactivity should appear first in the precursor and then in its metabolites. On this basis, the first experiment excludes that the esters (6) can be the precursors of polygodial (4), while the second experiment excludes the inverse biogenetic relationship. Therefore, in D. Iimbata, independent pathways could lead to the synthesis of $\underline{4}$ and $\underline{6}$. The results obtained are summarized in Table 1.

TABLE 1. Incorporation of label from $[2-14 \mathrm{C}]$-mevalonic acid into the metabolites of $\mathrm{D}$. limbata at various times

\begin{tabular}{|c|c|c|c|c|c|c|}
\hline $\begin{array}{c}\begin{array}{c}\text { Experiment } \\
(\mathrm{hr})\end{array} \\
\end{array}$ & $\begin{array}{c}\text { Animals } \\
\text { No. }\end{array}$ & $\begin{array}{c}\text { Polygodial (ㄴ) } \\
\mathrm{mg}\end{array}$ & $\begin{array}{c}\text { Activity } \\
\text { dpm/mg }\end{array}$ & $\begin{array}{c}\text { Esters (6) } \\
\mathrm{mg}\end{array}$ & $\begin{array}{c}\text { Activity } \\
\mathrm{dpm} / \mathrm{mg}\end{array}$ & $\begin{array}{c}\text { Euryfuran ( 7) } \\
\mathrm{dpm} / \mathrm{mg}\end{array}$ \\
\hline $\begin{array}{c}\operatorname{March} 1984 \\
(3) \\
(19) \\
(28)\end{array}$ & $\begin{array}{l}3 \\
3 \\
3\end{array}$ & $\begin{array}{r}2 \\
12 \\
9\end{array}$ & $\begin{array}{r}965 \\
11,300 \\
16,500\end{array}$ & $\begin{array}{l}27 \\
35 \\
33\end{array}$ & $\begin{array}{r}127 \\
2,300 \\
5,500\end{array}$ & $\begin{array}{r}185 \\
3,700 \\
10,800\end{array}$ \\
\hline $\begin{array}{c}\text { April } 1984 \\
(6) \\
(20) \\
(48) \\
(77)\end{array}$ & $\begin{array}{l}4 \\
4 \\
4 \\
2\end{array}$ & $\begin{array}{r}12 \\
9 \\
8 \\
2\end{array}$ & $\begin{array}{r}890 \\
3,800 \\
7,800 \\
14,500\end{array}$ & $\begin{array}{l}32 \\
30 \\
23 \\
12\end{array}$ & $\begin{array}{r}680 \\
2,800 \\
5,950 \\
7,100\end{array}$ & $\begin{array}{r}1,100 \\
4,000 \\
12,200 \\
14,200\end{array}$ \\
\hline
\end{tabular}

A total of $4.5 \mu \mathrm{Ci}\left(9.9 \times 10^{6} \mathrm{dpm}\right)$ of $[2-14 \mathrm{C}]$ mevalonic acid was injected into the digestive glands of 9 animals in the March experiment, whereas in the April experiment a total of $7 \mathrm{\mu Ci}\left(15.4 \times 10^{6} \mathrm{dpm}\right)$ of labelled precursor was injected into 14 animals. The radioactivity associated with the terpenoid part of the esters (6) was deduced after conversion into euryfuran ( 7 ) .

We can conclude that among the opisthobranch molluscs some dorid nudibranchs have elaborated the most sophisticated defence, biosynthesizing harmful drimane sesquiterpenoids which are stcired in skin glands to avoid suffering from their noxious effects. Strangely enough, it seems that a precursor-product relationship between these chemical weapons and the related but unactive esters, found in the digestive glands, should be excluded.

Research on other Mediterranean opisthobranch molluscs is in the first phase, namely the characterization of new metabolites. For instance, Janolus cristatus is a beautifully coloured nudibranch living in the bay of Naples. 
From the n-butanol solubles of an acetone extract of the whole animals a lipotripeptide was isolated (0.3 mg/animal) and named janolusimide (17) (ref. 21). The structure of the three amino acids was primarily deduced from a detailed analysis of monodimensional and 2D NMR spectra and then confirmed by degradation. Mild alkaline hydrolysis of janolusimide yielded the ketoamide 18 , while $\mathrm{NaBH}_{4}$ reduction gave the hydroxyamide 19 as a mixture of diastereoisomers. Acid hydrolysis yielded N-methylalanine (20), 4-amino-3-hydroxy-2-methylpentanoic acid (2l) and, as minor component, 4-amino-2-methyl-2-pentenoic acid (22), clear $\overline{l y}$ derived from dehydration of 21 .<smiles>CNC(C)C(=O)NC(C)C(O)C(C)C(=O)ON1C(=O)C(C)(C)C(=O)C1C(C)C</smiles><smiles>CNC(C)C(=O)O</smiles><smiles>CC(N)C(O)C(C)C(=O)O</smiles><smiles>CC(=CC(C)N)C(=O)O</smiles>

The sequence was deduced by NOESY experiments. In particular, the proton on the $\alpha$-carbon atom of the N-methylalanine residue exhibited n.o.e. with both the amidic $\mathrm{NH}$ and with the $\mathrm{N}$-methyl protons, indicating the sequence depicted in 17. Lipopeptides have been isolated from other marine invertebrates and algae (refs. 22,23), but it is the first time that a representative of such a class of compounds has been isolated from a nudibranch.

Aglaja depicta is an Aglajidae opisthobranch and, as Navanax inermis, member of the same family, is a predator of other opisthobranchs. The major metabolite found in the diethyl ether solubles from the acetone extracts of the digestive gland of the opisthobranch, named aglajne - 1 (23) (3.4 mg/animal), showed a MS molecular ion at $\mathrm{m} / \mathrm{z} 388$ too small for allowing high resolution mass measurements. However this ion, in conjunction with the I3C-NMR data, allowed us to obtain the molecular formula $\mathrm{C}_{2} 5 \mathrm{H}_{4} 0 \mathrm{O}_{3}$. The assignment of all the ${ }^{1} \mathrm{H}-$ and ${ }^{13} \mathrm{C}-$ NIR chemical shifts and, also, of all the ${ }^{1} \mathrm{H}$ coupling constants was made possible through a combination of mono-dimensional and two-dimensional (2D) NMR methods, which led to the partial structures a -- d, separated by 3 carbonyl groups. Two heteronuclear long-range correlations using 5 and $10 \mathrm{~Hz}$ as J values allowed us to complete the C-C connectivity of aglajne-1, as shown in 23 (ref.24).

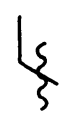

a

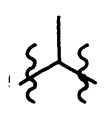

b

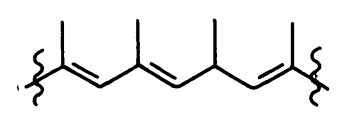

c<smiles>[Y]C(C)(C)CC(C)CC</smiles>

d<smiles>CCC(=O)C(S)C(=O)/C(C)=C/C(C)=C/C(C)=C/C(C)=C(\P)C(=O)C(C)CC</smiles> 
Significant long-range couplings were observed for the carbons of the 3 carbonyls, in particular, $\mathrm{C}-3$ showed couplings with the hydrogensi at $\mathrm{C}-\mathrm{l}$ and $\mathrm{C}-5$, the $\mathrm{C}-6$ carbonyl with those at $\mathrm{C}-5, \mathrm{C}-8$ and $\mathrm{C}-9$, and the $\mathrm{C}-18$ carbonyl with the hydrogens at C-15, C-17, C-20 and C-21. Surprisingly, aglajne-1 (23) shows in its structure the presence of a completely non-enolized $\beta$-diketone moiety, linked to a diene chromophore. This feature was confirmed by the shifts induced by alkali in both UV and ${ }^{1}$ H-NMR spectra. The suggested structure (23) was finally confirmed by treatment of aglajne-l with $\mathrm{NH}_{2} \mathrm{OH}-\mathrm{HCl}$ which yielded two isomeric isoxazole derivatives. Polypropionate derivatives have been found in some marine invertebrates, including sacoglossans (refs. 25,26) and pulmonates (ref. 27) but, usually, these compounds contain r-pyrone rings or cyclic hemiketals in their structures, while aglajne-1 (23) is an example of an acyclic polypropionate.

The analysis of the metabolites from the skin of A.depicta excluded the presence of polypropionate metabolites but showed, even though in minute amount (0.2 mg/animal), the presence of adenosine 24 . It joins the other nucleosides found in nudibranchs such as 1-methylisoguanosine (25), from Anisodoris nobilis (ref. 28) and isoguanosine (26) from Dianlula sandiegensis (ref. 29) $\overline{\text {. All }}$ these compounds produce cardiovascular effects, slowing down of the heart and hypotension, in mice and guinea pigs (ref. 30). However, for the moment, defensive roles of these molecules have not been firmly established, even though strongly suspected.

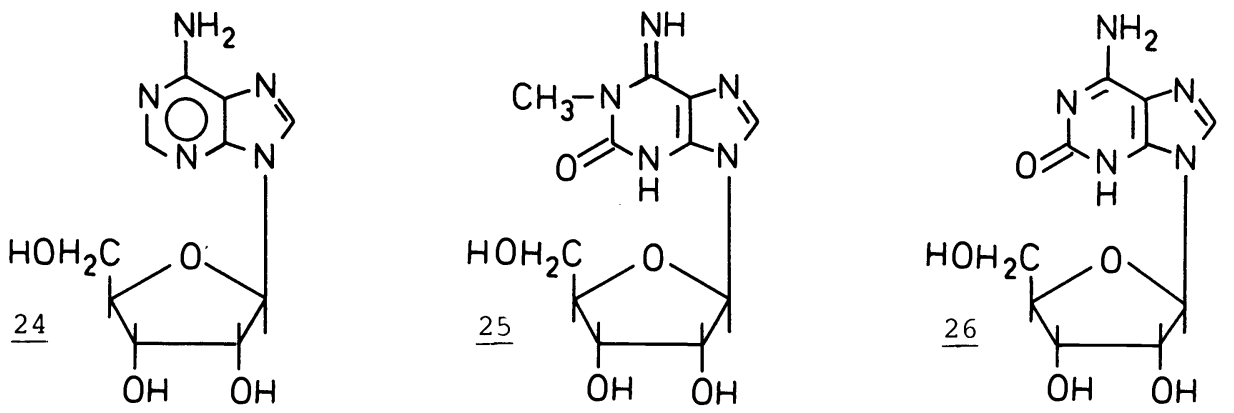

\section{MARINE ZOOCHROMES}

Marine zoochromes have been neglected by chemists in recent years despite the presence in the literature of several early reports (ref. 2) indicating the existence in marine invertebrates of unusual unidentified pigments. Marine invertebrates are often beautifully pigmented but either the small percentage of coloured materials or the difficult isolation, or the instability of the compounds prevented studies. The structure of few pigments has been elucidated in the last decade. Amongst those worthy of mention are bonellin, the biologically active pigment of the echurian worm Bonellia viridis (ref. 31) and uranidine (27), the highly unstable pigment of the sponge Verongia aerophoba (ref. 32), described for the first time a century ago (ref. 33).

Only recently an occasional field observation led us to investigate the structure of uranidine (27). In fact, during our research on Mediterranean opisthobranchs, Tylodina perversa (Notaspidea) was observed grazing on Verongia aerophoba. From the butanol solubles of the acetone extracts of the sponge the yellow pigment, which determines the rapid blackening of the sponge when exposed to air, was collected by chromatography on Sephadex LH 2O. On the basis of the spectral evidence "uranidine" has to be a 3,5,8-trihydroxy-4-quinolone (27) which in alkaline solution is oxidized by air oxygen to quinone (28) . The quinone then rapidly polymerizes giving black compounds. This reactivity has been well observed by recording, during oxidation, a series of $500 \mathrm{MHz}{ }^{1} \mathrm{H}-\mathrm{NMR}$ spectra. In this manner it was possible to record the spectrum of the quinone, stable for only a few minutes before the appearance of the black compounds.<smiles>O=c1c(O)c[nH]c2c(O)ccc(O)c12</smiles><smiles>O=C1C=CC(=O)c2c1[nH]cc(O)c2=O</smiles> 
The sea-worm Halla parthenopeia shows a red colour due to the presence of hallachrome ( $\underline{29})$, whose structure was elucidated by Prota et al. in 1972 (ref.34). Hallachrome is the unique representative of naturally occurring 1,2-anthraquinone unsubstituted at positions 9 and 10. A recent study (ref.35) on $\mathrm{H}$. parthenopeia has revealed that by modifying the technique of extraction, it is possible to obtain along with hallachrome a more polar major compound (30) closely related to 29 .<smiles>COc1c(O)c(C)cc2cc3c(cc12)C(=O)C(=O)C=C3</smiles>

29<smiles>COc1c(O)c(C)cc2cc3ccc(O)c(O)c3cc12</smiles>

30

In fact the molecular formula, $\mathrm{C}_{16} \mathrm{H}_{14} \mathrm{O}_{4}$, obtained by high resolution mass measurements on the molecular ion at m/z 270, suggested that 30 should be a dihydro derivative of 29. This hypothesis was further supported by the analysis of the ${ }^{1}$ H-NMR spectrum of. 30, strongly reminiscent of that of 29 . Acetylation of 30 yielded a triacetate identical to the leucotriacetate of 29 . A series of n.O.e. experiments on this compound confirmed the substitution pattern of $\underline{29}$ and $\underline{30}$.

The very long sea-worm (almost $60 \mathrm{~cm}$ ) Halla parthenopeia is well known to the Neapolitan anglers. In fact, it is used as bait. The same use is reserved for another sea-worm, the red Lumbriconereis impatiens. Our analysis has also revealed in this worm the presence of large amounts of trihydroxy-methoxy-anthracene (30) above described, along with hallachrome, which in this case is present only in small traces. The different ratios between hallachrome and its biogenetic precursor (30), found in the two sea-worms, suggest that in vivo an enzymic control regulates this conversion. Hallachrome is an $\overline{a c}$ id sensitive molecule. In fact, it was reported (ref. 36) that the extraction of the worm with acetic acid yielded, instead of 29, a violet pigment which was not further investigated. It has now been demonstrated (ref. 37) that treatment of hallachrome with methanol containing $\mathrm{HCl}$ or $\mathrm{BF}_{3}$ affords a violet isomer for which the structure 31 has been assigned by n.O.e.experiments. The reaction proceeds through the nor-derivative (32), isolated after treatment of 29 with $\mathrm{HCl}$ in dioxane, which can be transformed regiospecifically into 31 by $\overline{\mathrm{CH}}_{3} \mathrm{OH} / \mathrm{BF}_{3}$. To justify the easy methylation it has been pointed out that the reaction should have an intermediate, such as the extended quinone 33 , which, being vinylogous to a carboxylic acid, could be easily methylated.<smiles>COc1ccc2cc3c(cc2c1O)C(=O)C(=O)C(C)=C3</smiles>

31<smiles>CC1=Cc2cc3ccc(O)c(O)c3cc2C(=O)C1=O</smiles>

$\underline{32}$<smiles>CC1=Cc2cc3c(cc2=C(O)C1=O)C(=O)C(O)=CC=3</smiles>

$\underline{33}$

In 1940 (ref. 38), Lederer reported the isolation of a pigment from the sea anemone Calliactis parasitica, named calliactine, for which he proposed a molecular composition of $\mathrm{C}_{2} \mathrm{H}_{2} \mathrm{~N}_{4} \mathrm{O}_{5}$ by elemental analysis. Calliactine acts as a $\mathrm{pH}$ indicator, changing ${ }^{2} \mathrm{t}^{2}$ colour from orange (acid) to blue (alkaline), and is transformed sequentially into "chlorocalliactine" by boiling dilute $\mathrm{HCl}$ ' and "neocalliactine" by boiling water. In 1982 (ref. 39) Barbier, reporting the results of 10 year's work on calliactine ("a most frustrating problem"), proposed that the elemental formula should be revised to $\mathrm{C}_{2}{ }_{1} \mathrm{H}_{22} \mathrm{~N}_{4} \mathrm{O}_{5}$ (MS data) and pointed out that calliactine should be considered a paramagnetic substance since it did not give useful signals in ${ }^{1} \mathrm{H}-$-nd ${ }^{13} \mathrm{C}-\mathrm{NMR}$ using a variety of solvents. 
Our work on calliactine started in 1969 and was unsuccessful for many years. only recently have we succeeded in setting up a chromatographic isolation procedure (cellulose) which allows access to pure samples of calliactine. We simultaneously discovered that the failure to give NMR spectra was only due to the extremely unfavourable solubility properties of calliactine. In fact, only freshly prepared material can be kept in solution for several hours before precipitation. Therefore $8-9 \mathrm{mg}$ samples were dissolved in $\mathrm{CD}_{3} \mathrm{OD}-\mathrm{CD}_{3} \mathrm{COON}$ (best solvent) and used for NMR spectroscopy. The molecular composition of calliactine was established as $\mathrm{C}_{18} \mathrm{H}_{1}{ }_{4} \mathrm{~N}_{4} \mathrm{O}_{2}$ by FAB-MS, which gave the quasi-molecular ion $(\mathrm{M}+\mathrm{H})$ at $\mathrm{m} / \mathrm{z} 319$, and by E.I. HRMS on the ion at $\mathrm{m} / \mathrm{z} 300\left(\mathrm{M}^{+}-\mathrm{H}_{2} \mathrm{O}\right)$. Four nitrogen atoms were also present in the molecular formulae reported by Lederer and Barbier; one of the nitrogen atoms is involved in an imino function (see below). The molecular composition is also supported by the $13 \mathrm{C}-\mathrm{NMR}$ spectrum which displays 18 distinct resonances, three sp ${ }^{3}$ carbons and $15 \mathrm{sp}^{2}$ carbons. The ${ }^{1}$ H-NMR spectra of calliactine are very simple, displaying five protons linked to $\mathrm{sp}^{3}$ carbons and five aromatic protons. The chemical shift and coupling constant values, together with the comparison with model compounds, suggested the presence of partial structures $\underline{e}-\underline{g}$.<smiles>C=C1C(C)=NCCC1O</smiles>

$\underline{\mathrm{e}}$<smiles>Cc1ccnc(C)c1C(C)(C)C</smiles>

$\underline{\mathrm{f}}$<smiles>Cc1cc(O)ccc1NC(C)(C)C</smiles>

$\underline{9}$

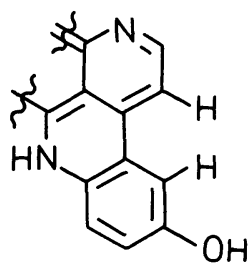

$\underline{\mathrm{h}}$

Partial structures $\underline{f}$ and $\underline{g}$ should be connected as depicted in $\underline{h}$ since a pos--.. itive n.O.e. was experienced between the displayed protons. Owing to the presence of the unstable hydroxy-tetrahydropyridine ring and of the easily hydrolyzed imine functionality, even simple derivatization reactions carried out on calliactine lead to intractable mixtures. However treatment of calliactine with boiling dilute HCl followed by acetylation yielded a single compound $\mathrm{C}_{2} \mathrm{H}_{1} \mathrm{H}_{3} \mathrm{O}_{3}$ which should be considered as the acetate of the "neocalliactine" described by Lederer. This derivative displays more favourable solubility properties. Inspection of NMR spectra of neocalliactine acetate revealed that the acid treatment induced at the same time aromatization of the tetrahydropyridine ring and hydrolysis of the imino group. At this stage neocalliactine could be formulated as one of the $\underline{34}-\underline{37}$ structures.<smiles></smiles>

$\underline{34}$<smiles></smiles>

35<smiles>O=C1c2ncccc2-c2nc3ccc(O)cc3c3ccnc1c23</smiles>

36<smiles>O=C1c2cccnc2-c2nc3ccc(O)cc3c3ccnc1c23</smiles>

37

Structures 35 and 37 include nitrogen atoms in the same relative position as in 1,10-phenanthroline, the well-known metal chelating agent. However, neocalliactine does not show any metal chelating ability and therefore structures 35 and 37 should be ruled out. Aromatization of the tetrahydropyridine ring without hydrolysis was achieved by gently warming methanolic solutions of calliactine absorbed on silica gel. The compound obtained in this reaction, after acetylation, could be formulated either as 38 or 39 on the basis of its spectral properties. At the time of writing this paper we do not have arguments to distinguish structures 38 and 39 (or structures 34 and 36 for neocalliactine) and therefore calliactine could be represented either by structure 40 or by structure 41. We believe that only X-rays or total synthesis could distinguish the two structures. Calliactine is obviously a compound of a new skeletal type. It is however reminiscent of amphimedine (42), an aromatic alkaloid recently isolated from a Pacific sponge, whose structure has been elucidated by doublequantum experiments (ref. 40). 
<smiles>C=CNc1c2ncccc2c2c3nccc(c13)-c1cc(OC(C)=O)ccc1N2</smiles><smiles>CC(=O)Nc1c2ncccc2c2c3c(ccnc13)-c1cc(OC(C)=O)ccc1N2</smiles><smiles>N=c1c2c3c(c4nccc(c43)c3c1[nH]c1ccc(O)cc13)=NCC[C@H]2O</smiles><smiles></smiles><smiles>Cn1cc2c(cc1=O)C1=Nc3ccccc3C3C=CN=C(C2=O)C13</smiles>

\section{NEW ALKALOIDS FROM RENIERA SARAI}

The last part of this lecture is devoted to the structural investigation of the nitrogenous metabolites of the sponge Reniera sarai. This sponge is easily collected in the Bay of Naples and contains a series of new metabolites in the very abundant ( 6 \% dry weight) n-butanolic solubles from the acetone extracts. Our interest in these metabolites began in 1970, but only now have we been able to partially characterize some of these compounds. The first difficulties were encountered during the isolation work and they were ascribed to the formation of complexes between the new molecules and the salts present on the chromatographic substrates. However, we were able, through a series of fast chromatographic steps, to isolate in high yields three compounds named in order of increasing polarity: sarain-1, sarain-2 and sarain-3. At the moment, our main interest is limited to the structural elucidation of these three molecules, even though minor components, related to sarains, are also present in the extracts along with a very abundant ( $30 \%$ of the butanolic extract) UV absorbing fraction. The molecular formulae of sarains were established as $\mathrm{C}_{31} \mathrm{H}_{50} \mathrm{~N}_{2} \mathrm{O}, \mathrm{C}_{30} \mathrm{H}_{50} \mathrm{~N}_{2} \mathrm{O}$ and $\mathrm{C}_{32} \mathrm{H}_{52} \mathrm{II}_{2} \mathrm{O}$ by high resolution mass measurements on the molecular ions at m/z 466, 454 and 480, respectively. All the compouncis possessed a ketone carbonyl, two tertiary nitrogen atoms and a trisubstituted double bond; sarain-1 and -3 showed an additional bisubstituted double bond. The mass spectra of all the sarains were characterized by the same strong fragment at $\mathrm{m} / \mathrm{z} 327$, which appeared also in the mass spectra of the dihydro derivatives of sarain-1 and -3, obtained by catalytic hydrogenation of the bisubstituted double bond, while it was shifted to $\mathrm{m} / \mathrm{z} 329$ in the mass spectra of the secondary alcohols obtained by reduction of the carbonyl group of the three sarains. Accurate mass spectral measurements ascertained that these fragments retain all the heteroatoms. According to the unsaturation, in all the sarains, a pentacyclic skeleton containing the carbonyl and the double bonds can be suggested. As the $100 \mathrm{MHz}{ }^{1} \mathrm{H}-\mathrm{NMR}$ spectra of sarains were uninterpretable, showing almost all the high-field protons unresolved, we strongly desired the aid of a resolutive diffractometric analysis. Unfortunately, it has not so far been possible to crystallize the sarains or to obtain their crystalline derivatives. However, the recent great development of new techniques applicable to structural work has stimulated our engagement to establish the structures of these molecules by appropriate spectroscopic studies.

${ }^{1} \mathrm{H}$ and ${ }^{13} \mathrm{C}$-NMR spectra of sarains showed that sarains belong to an homologous series containing a common tetracyclic nucleus and having different alkyl chains connecting the rings. Spectroscopic investigations on sarain-1 are reported here. The $500 \mathrm{MHz}{ }_{\mathrm{H}-\mathrm{NMR}}$ spectrum of sarain-1, even though complex, showed well-resolved signals. A combination of mono-dimensional and two-dimensional (2D) NMR methods allowed us the assignments of almost all the ${ }^{1} \mathrm{H}$ and ${ }^{13} \mathrm{C}$ chemical shifts and, in particular, brought evidence for the partial structures $\underline{i}, \underline{1}$ and $\underline{m}$. The relevant NIIR assignments of sarain-1 are reported in Tablè 2 . 


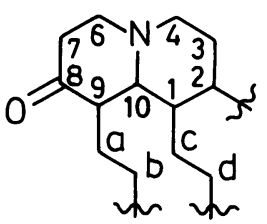

i

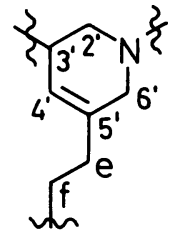

1

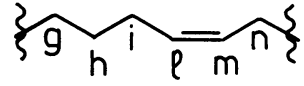

$\underline{\mathrm{m}}$

TABLE 2. Relevant NMR data of sarain-1

\begin{tabular}{|c|c|c|c|c|c|}
\hline Position & $\delta{ }^{13} \mathrm{C}$ & $\delta{ }^{1} \mathrm{H}$ & Position & $\delta{ }^{13} \mathrm{C}$ & $\delta{ }^{l} \mathrm{H}$ \\
\hline 1 & 36.3 & 1.98 & a & 21.2 & $1.68,1.30$ \\
\hline 2 & 37.2 & 1.85 & $\mathrm{~b}$ & 25.6 & $1.46,1.60$ \\
\hline 3 & 24.5 & 1.75 & C & 36.8 & $1.25,1.52$ \\
\hline 4 & 46.3 & $3.02,2.57$ & $\mathrm{~d}$ & 23.7 & $1.2,1.5$ \\
\hline 6 & 54.6 & $3.15,2.68$ & e & 31.6 & $1.91,2.15$ \\
\hline 7 & 38.7 & $2.20,2.70$ & $f$ & 24.2 & $1.58,1.42$ \\
\hline 8 & 210.8 & - & g & 56.6 & $2.40,2.36$ \\
\hline 9 & 52.9 & 2.35 & $\mathrm{~h}$ & 26.5 & $1.69,1.3$ \\
\hline 10 & 68.8 & 2.07 & i & 24.3 & $1.85,2.4$ \\
\hline $2^{\prime}$ & 54.8 & $2.22,2.65$ & 1 & 129.3 & 5.42 \\
\hline $3^{\prime}$ & 40.4 & 2.36 & $\mathrm{~m}$ & 130.3 & 5.42 \\
\hline $4^{\prime}$ & 121.8 & 5.48 & $\mathrm{n}$ & 24.8 & $1.91,2.16$ \\
\hline $5^{\prime}$ & 135.9 & - & & & \\
\hline $6^{\prime}$ & 55.0 & $2.42,3.10$ & & & \\
\hline
\end{tabular}

Besides the reported chemical shift values, in the ${ }^{13} \mathrm{C}$ spectrum there were other resonances at $\delta 27.2(2 \mathrm{C}), 26.7,26.5$ and 24.4 attributable to methylene carbons in alkyl chains. The presence of a coupling between $\mathrm{H}-2$ and $\mathrm{H}-3^{\prime}, \mathrm{Ob}-$ served in the COSY spectrum, allowed us to link the quinolizidine system to the tetrahydropyridine ring. The ${ }^{13} \mathrm{C}$ resonance at $\delta 56.6$ located $\mathrm{C}-\mathrm{g}$ on the nitrogen atom of the structure 1 . On the basis of all these data the framework of sarain-l has to contain a trisubstituted quinolizidine structure linked to a trisubstituted tetrahydropyridine ring. The other 17 carbons are arranged in two linear alkyl chains which connect the two above described partial structures. The chain starting from the nitrogen atom should contain at least 10 carbon atoms. In fact, as mentioned above, in the mass spectrum of sarain-l, as well as in those of the other sarains, a strong fragment at $\mathrm{m} / \mathrm{z}$ 327, which retains all the heteroatoms, is present. On this basis the second alkyl chain should not contain more than seven carbons. A tentative structure of sarain-l is shown in Fig. 1. Of course, the longer alkyl chain could be linked either at $\mathrm{C}-1$ or at $\mathrm{C}-9$, even though we prefer the first hypothesis on the basis of the analysis of the Dreiding models, which gave in the second case a too-crowded structure.

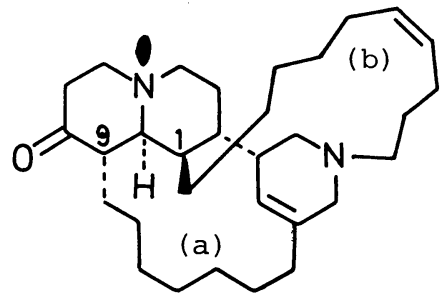

Fig.l Tentative structure of sarain-l. The linkages of the alkyl chains at C-l and $c-9$ could be rejversed. A total of 17 carbon atoms are in the chains (a) and(b). The length of (a) and(b)can vary, but they have to contain at least 10 and 4 carbons, respectively.

The analysis of ${ }^{1} \mathrm{H}$-NMR spectra allowed us to make various conjectures regarding the stereochemistry of sarain-l. First of all, a trans conformation was assigned to the quinolizidine ring on the basis of the high-shifted ${ }^{1} \mathrm{H}-\mathrm{NMR}$ value of $\mathrm{H}-10$. The shape of the signal, a broad doublet, offered evidence for 
the stereochemistry of the two adjacent chiral centres, suggesting an equatorial orientation of the substituent on $\mathrm{C}-9\left(\mathrm{~J} \mathrm{H}_{10}-\mathrm{H}_{9}=1 \mathrm{~Hz}\right)$ and an axial orientation of that on $\mathrm{C}-1$. The upfield position at $\delta 46.3$ of $\mathrm{C}-4$ can be justified by the $\gamma$-shielding effect of the axial substituent on $\mathrm{C}-2$. Finally, an observed $\mathrm{W}$-coupling between $\mathrm{H}-4{ }^{\prime}$ and the equatorial $\mathrm{H}-2{ }^{\prime}$, allowed us to infer a cis - relationship between the axial $\mathrm{H}-2$, and $\mathrm{H}-3^{\prime}$. Chemical work was prevented due to the difficult handling of sarains. We were able to obtain only a few simple derivatives of sarain-1, such as the 8-hydroxy and the corresponding acetoxy derivatives. The spectroscopic analysis of these derivatives confirmed the above assignments. Sarain-l is the first example of a new class of macrocyclic alkaloids. It is worth noting that recently the structures of other quinolizidine alkaloids of marine origin,such as petrosin (43) from the sponge Petrosia seriata (ref. 41) and xestospongin-C (44) from Xestospongia exigua (ref. 42), were determined by X-ray analysis, while some years ago a series of toxic cyclic N-alkylated pyridine salts were isolated from several sponges of the genus Halichlona and partially characterized (ref. 43). A common biogenetic origin could link all these macrocyclic compounds.
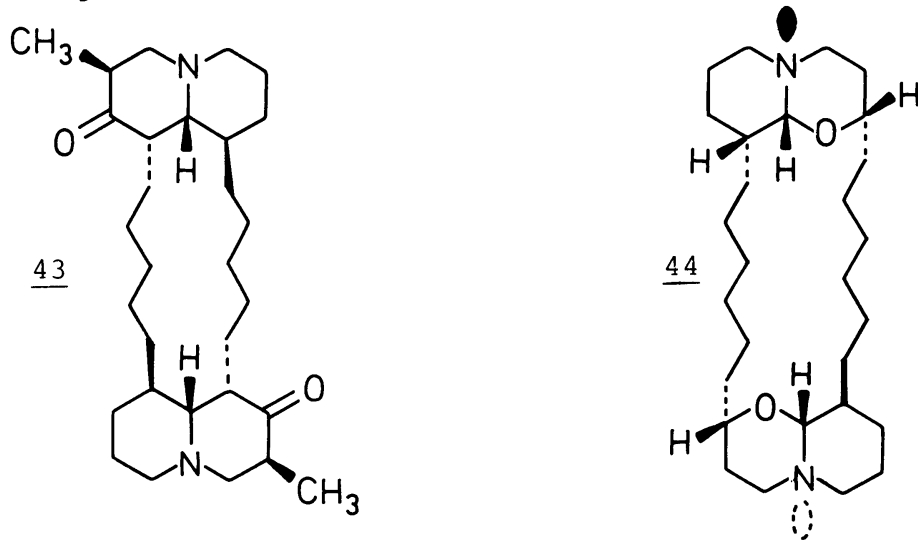

Petrosin is toxic to fish, whereas xestospongin-C and its co-occurring related alkaloids are vasodilatative compounds. Sarains, furthermore, showed antiarrythmic effects: but a moderate toxicity ( $\mathrm{LD}_{50} 200 \mathrm{mg} / \mathrm{Kg}$ on mice) prevented further analysis of their pharmacological activities. The capacity to form stable complexes with salts gives to sarains properties comparable to those of the crown-ethers. In fact saraintis able to solubilize potassium acetate in benzene. In this manner, the solubilized acetate becomes sufficiently nucleophilic to react with highly activated bromides, such as benzyl bromide, producing benzyl acetate in a yield (75\%) comparable to that obtained $(82 \%)$ when the reaction is catalyzed by $18-$ crown -6 .

\begin{abstract}
Acknowledgement This research was supported in part by the "Progetto Finalizzato per la Chimica Fine e Secondaria", C.N.R., Roma. We thank Professors L. Minale, Naples, and R. H. Thomson, Aberdeen, for the advice and discussions which were very much appreciated. We also thank Drs. M. Gavagnin, A. Spinella and E. Trivellone for their contributions in the work presented in this paper. Finally we thank A. Crispino, G. Scognamiglio, A. Trabucco and R. Turco for their skilful technical assistance.
\end{abstract}

\title{
REFERENCES
}

1. D. J. Faulkner, Natural Product Reports, 1, 551 (1984).

2. A. E. Needham, The Significance of Zoochromes, Springer-Verlag, BerlinHeidelberg-New York (1974).

3. T. E. Thompson, Biology of Opistobranch Molluscs-I, The Ray Society, London (1976).

4. T. E. Thompson, J. Mar. Biol. Ass. U.K., 39, 115 (1960).

5. D. J. Faulkner and M.T. Ghiselin, Mar. EcoI. Prog. Scr. 13, 295 (1983).

6. B. J. Burreson, P. S. Scheuer, J. Finer and J. Clardy, J. Am. Chem. Soc. 97, 201 (1975).

7. G.'Cimino, S. De Rosa, S. De Stefano and G. Sodano, Comp. Biochem. Physiol. 73B, 471 (1982).

8. J. E. Thompson, R. P. Walker, S. J. Wratten and D. J. Faulkner, Tetrahedron $\underline{38}, 1865$ (1982). 
9. K. Gustafson and R. J. Andersen, Tetrahedron, 4l, 1101 (1985).

10. G. Cimino, S. De Rosa, S. De Stefano, R. Morrone and G. Sodano, Tetrahedron, 41,1093 (1985).

11. G. R. Schulte and P. J. Scheuer, Tetrahedron, 38, 1857 (1982).

12. R. K. Okuda, P. J. Scheuer, J. E. Hochlowski, R. P. Walker and D. J. Faulkner, J. Org. Chem., 48,1866 (1983).

13. G. Cimino, S. De Rosa, S. Dè Stefano and G. Sodano, Tetrahedron Letters, $22,1271(1981)$.

14. G. Cimino, S. De Rosa, S. De Stefano, G. Sodano and G. Villani, Science, 219,1237 (1983) .

15. G. Cimino, S. De Stefano, A. Guerriero and L. Minale, Tetrahedron Letters, 3723 (1975).

16. F. Cafieri, E. Fattorusso, C. Santacroce and L. Minale, Tetrahedron, 28, $1579(1972)$.

17. I. Kubo and I. Ganijian, Experentia, 37, 1063 (1981).

18. K. Nakanishi and I. Kubo, Israel J. Chem., 16, 28 (1977).

19. G. Cimino, G. Sodano and A. Spinella, Tetrah̄edron Letters, 25, 4151 (1984).

20. G. Cimino, S. De Rosa, S. De Stefano and G. Sodano, Experientia, in press.

21. G. Sodano and A. Spinella, unpublished results.

22. R. E. Moore, Pure and Applied Chemistry, 54, 1919 (1982).

23. Ref. 1, references therein.

24. C. Cimino, G. Sodano, A. Spinella and E. Trivellone, Tetrahedron Letters, $28,3389(1985)$.

25. C. Ireland and P. J. Scheuer, Science, 205, 922 (1979).

26. C. Ireland and D. J. Faulkner, Tetrahedron, 37 suppl.1, 233 (1981).

27. J. E. Hochlowski, J. C. Coll, D. J. Faulkner, J. E. Biskupiak, C. M. Ireland, Z. Pi-Tai, H. Cun-Lang and J.Clardy, J. Am. Chem. Soc., 106, 6748 (1984), and references therein.

28. F. A. Fuhrman, G. J...Fuhrman, R. J. Nachmän and H. S. Mosher, Science, 212,557 (1981).

29. Y. H. Kim, R. J. Nachman, L. Pavelka, H. S. Mosher, F. A. Fuhrman and G. S. Fuhrman, J. Nat. Products, 44, 206 (1981).

30. P. N. Kaul, Pure and Applied Chemistry, 54, 1963 (1982).

31. A. Pelter, J. A. Ballantine, V. Ferrito, V. Jaccarini, A. F. Psaila and P. J. Schemkri, Chem. Comm., 999 (1976).

32. G. Cimino, S. De Rosa, S. De Stefano, A. Spinella and G. Sodano. Tetrahedron Letters, 25, 2925 (1984).

33. C. F. W. Krukenberg, Vergl. Physiol. Studien, Inst. Heidelberg 2, Abt. 3, 1 (1882).

34. G. Prota, M. D. Agostino and G. Misuraca, J. Chem. Soc. Perkin I, 1614 (1972).

35. G. Cimino, S. De Rosa, S. De Stefano and G. Sodano, J. Nat. Prod., in press.

36. H. J. Bielig and H. Mollinger, Z. Physiol. Chem., 321, 276 (1960).

37. M. D'Agostino, S. Crescenzi, G. Prota, S. De Rosa and G. Sodano, Journ. Nat. Prod., submitted.

38. E. Lederer, G. Tessier, C. Huttrer,Bull. Soc. Chim., France, 7, 608 (1940).

39. M. Barbier, Naturwissenschaften, 69, 341 (1982).

40. F. S. Schmitz, S. T. Agarwal, S. P. Gunasekera, P. J. Schmidt and J. N. Shoolery, J. Am. Chem. Soc., 105, 4836 (1983).

41. J. C. Braeckman, D. Daloze, P. Macedo de Abreu, C. Piccinni-Leopardi, G. Germain,M. Van Meerssche, Tetrahedron Letters, 23, 4277 (1982).

42. M. Nakagawa and M. Endo, Tetrahedron Letters, 25,3227 (1984).

43. F. J. Schmitz, K. H. Hollenbeak and D. C. Campbell, J. Org. Chem., 43 , $3916(1978)$. 